\title{
Hart, Jennifer Ghana on the Go: African Mobility in the Age of Motor Transportation
}

Fernanda Pandolfi *

Bloomington (Indiana, USA): Indiana University Press, 2016. 250p.

A principal contribuição de Ghana on the Go é abordar a questão da mobilidade social na África colonial focalizando uma variável explicativa pouco intuitiva: o advento do transporte motorizado na Costa do Ouro (atual Gana) na década de 1910. O livro mostra que mesmo os africanos mais pobres eram capazes de identificar, nas brechas do regime colonial, formas de empreender, o que contradiz a interpretação de boa parte da literatura sobre o tema, a qual explícita ou implicitamente assume uma inadequação das populações nativas africanas ao desenvolvimento de ideias e técnicas vindas de fora. Ao abordar a questão dessa perspectiva, o livro amplia a discussão sobre mobilidade social, incluindo aspectos que vão além da maior mobilidade física propiciada pelos veículos a motor, como o impacto da nova tecnologia na configuração de valores, experiências e oportunidades criados no cotidiano.

De maneira mais ampla, o trabalho insere-se em campo que tem reavaliado a história da tecnologia na África. Em estudo pioneiro, James Ferguson (1999) mostrou que o efeito das mudanças tecnológicas sobre as populações africanas não ocorre linearmente em direção a um padrão semelhante ao dos países ocidentais. Seguindo essa linha de argumentação, Ferguson identificou na Zâmbia, entre as décadas de 1930 e 1970, a existência de dois modos de vida bastante independentes um do outro: o "localista" (que enfatizava valores rurais e tradicionais) e o "cosmopolita". Segundo Ghana on the Go, tais modos de vida encontravam-se mais conectados. Em outro eixo de análise, o recente

\footnotetext{
* Universidade Federal do Espírito Santo (UFES), Programa de Pós-Graduação em História. Vitória, ES, Brasil. ferpandolfi@hotmail.com <https://orcid.org/0000-0001-9429-4561>
} 
trabalho de Clapperton Mavhunga (2014) qualifica os africanos como "criadores" ("designers", "designer-users") que aplicavam a tecnologia a seu modo na resolução dos problemas cotidianos, contrapondo-se, dessa maneira, à visão dos africanos como vítimas ou meros receptores de novas tecnologias. Hart desdobra essas ideias para o campo da cultura, ao enfatizar como os africanos não meramente se apropriaram dos valores associados à tecnologia ocidental, mas criaram sua própria versão da modernidade.

A essa abordagem a autora acrescenta referências da história do cotidiano como Michel de Certeau (1994) e Henri Lefebvre (1991) e os conceitos de habitus e capital social de Pierre Bourdieu (1990) para analisar os amplos efeitos culturais e econômicos da introdução da tecnologia do transporte motorizado em Gana na vida das pessoas comuns.

Dialogando com essa literatura em torno de tais desdobramentos e contrapontos, Hart focaliza a importância do transporte motorizado nas colônias africanas e traz para os leitores uma interessante história de ascensão econômica e social das populações nativas em Gana, identificando uma sociedade colonial mais multifacetada do que a que se vê nas interpretações que se baseiam em categorias como "elites educadas", "trabalhadores assalariados" e "fazendeiros".

Um dos aspectos singulares de Gana, diferentemente do que ocorreu em outras colônias africanas, foi que o transporte motorizado comercial preponderou, operando em grande parte fora das estruturas e do apoio do Estado. Isso foi possível graças à riqueza proveniente do boom do cacau na década de 1920, que permitiu a muitos africanos adquirirem veículos para trabalhar como motoristas autônomos.

No primeiro capítulo a autora analisa as narrativas pessimistas dos administradores britânicos com a situação dos transportes, mostrando que ao invés de evidenciarem o fracasso na implantação do novo sistema de transporte, essas narrativas indicavam o amplo apoio dos africanos à nova tecnologia, os quais geriam as rotas e a logística de forma relativamente independente dos administradores coloniais.

O segundo capítulo trata do mundo do trabalho que emergia com o transporte motorizado, mostrando como se transmitiam os novos valores culturais, hábitos e atitudes. Nesse novo sistema, gerido pelos próprios africanos, os motoristas mais experientes (os "masters") integravam os aprendizes (os "mates") ao mundo do trabalho e das obrigações mais amplas na vida das comunidades, repassando-lhes capital cultural e social para atuarem no ramo. Entre os aprendizes inicialmente sobressaíam jovens com poucos recursos e baixa 
escolaridade. A partir das décadas de 1930 e 1940, entretanto, a profissão passou a atrair jovens com maior escolaridade que não encontravam mais vagas nas profissões que tradicionalmente os empregavam, como escriturários e lojistas. Foi nessa época que hábitos do mundo moderno, como o aumento do consumo de álcool, passaram a impactar a profissão. A difusão desse hábito, que representava risco para suas vidas - de passageiros e pedestres -, levou as autoridades a punirem mais severamente a embriaguez por meio de regulamentos progressivamente mais restritivos, o que acirrou a insatisfação dos motoristas com o governo colonial e teve importantes desdobramentos políticos nos anos seguintes.

Uma segunda linha de argumentação seguida pela autora é a demonstração de que nesse processo de crescente identificação com uma nova profissão e de oposição à autoridade colonial os motoristas forjavam uma cultura original, que se manifestava por exemplo na adaptação peculiar dos veículos, como no caso do icônico caminhão de pequeno porte apelidado "mammy wagon" em razão de seu amplo uso no transporte de mulheres.

O terceiro capítulo examina a "idade de ouro da profissão" nas décadas de 1930 a 1960, que demarca a consolidação do status social e econômico dos motoristas. Nesse universo cultural, dirigir representava um caminho alternativo para ascender econômica e socialmente, sobretudo para os que possuíam recursos e escolaridade limitados. A noção de respeitabilidade, tradicionalmente associada a figuras espirituais e chefes nativos detentores de poder e conhecimento, passa a associar-se também a indivíduos capazes de acumular riqueza e mobilizar recursos sociais, políticos e econômicos. A consolidação da profissão também foi marcada pela hierarquização interna, em que determinados tipos de motoristas passaram a melhorar seu status. Por exemplo, os motoristas de "mammy trucks", utilizados em longas distâncias, eram vistos como profissionais por possuírem maior treinamento e conhecimento para dirigir longos percursos. Um importante traço cultural desse período foi a disposição dos africanos em adaptarem os novos hábitos e atitudes trazidos pela mudança nos meios de transporte, por exemplo, empregando novos conceitos e expressões linguísticas como a palavra "anibue", utilizada pelos motoristas para se referirem àqueles experientes nas oportunidades propiciadas pela vida moderna.

O quarto capítulo descreve como as mudanças culturais que ocorreram com o emprego em massa de veículos a motor moldaram as relações políticas em Gana após a independência, em 1957. Inicialmente os políticos tentaram cooptar os motoristas, tendo o presidente Nkrumah incluído o transporte a 
motor em seu novo projeto nacional. Motoristas exibiam orgulhosamente o slogan "Nkrumah ama os motoristas", contribuindo para estabelecer um senso de pertencimento nacional. As boas relações dos motoristas com o novo governo, entretanto, foram passageiras. Diante das crescentes dificuldades econômicas, o novo governo passou a taxar cada vez mais pesadamente os motoristas, os quais, compreensivelmente, se recusavam a arcar com esse sacrifício. O governo passou então a acusá-los de descaso com o interesse público e a interferir cada vez mais na vida dos motoristas em seus aspectos econômicos e sociais. Nesse cenário de incertezas e ansiedade, os motoristas tornaram-se bodes expiatórios, publicamente condenados pela imprensa por empregar preços abusivos e obter lucros muitos superiores ao capital investido, sendo condenados como "inimigos públicos". Entre 1960 e 1980 - a "era do declínio" -, de respeitados empreendedores os motoristas passaram a ser considerados malandros, trapaceadores, mentirosos e ladrões.

O quinto capítulo explora as implicações do colapso mundial dos preços das commodities sobre a economia e a sociedade de Gana. A consequência principal da crise foi o comprometimento da importação do petróleo, o que afetou profundamente a economia do país, levando à migração, em especial dos homens, para a Nigéria. Nesse contexto, Gana não estava mais na estrada ("on the go") e a prosperidade esperada tornava-se cada vez distante. O caminho adotado para sanar a crise econômica passava pelo auxílio do Banco Mundial e pelos respectivos ajustes macroeconômicos.

No "Epílogo", a autora discute brevemente a situação dos transportes e dos motoristas profissionais em Gana no século XXI, destacando o aumento do número de carros particulares em detrimento do investimento em transporte coletivo. A consequência não prevista desse processo foram os grandes congestionamentos nas principais cidades e a queda nos rendimentos dos motoristas, o que tem alimentado um sentimento de nostalgia, uma vez que no passado a profissão de motorista simbolizava status.

Assim, longe de ser apenas uma história sobre a evolução dos meios de transportes em Gana, como o título poderia sugerir, o livro é uma importante referência para pesquisadores interessados em estudar os efeitos de mudanças tecnológicas sobre a economia, a cultura e as atitudes dos indivíduos em países pouco desenvolvidos. 


\section{REFERÊNCIAS}

BOURDIEU, Pierre. The Logic of Practice. Cambridge: Polity Press, 1990.

CERTEAU, Michel de. A invenção do cotidiano: artes de fazer. Petrópolis: Vozes, 1994. FERGUSON, James. Expectations of Modernity: Myths and Meanings of Urban Life on Zambian Copperbelt. Berkeley: University of California Press, 1999. (e-book, kindle ed.).

LEFEBVRE, Henri. A vida cotidiana no mundo moderno. São Paulo: Ática, 1991.

MAVHUNGA, Clapperton C. Transient Workspaces: Technologies of Everyday Innovation in Zimbabwe. Cambridge: The MIT Press, 2014. (e-book, kindle ed.).

Resenha recebida em 29 de junho de 2018. Aprovada em 27 de setembro de 2018. 